\title{
Modelo japonês e práticas de gestão na indústria de veículos sobre duas rodas no Brasil
}

\section{Japanese model and management practice in two-wheeled vehicles in Brazil: a case study}

Allison Santos de Andrade - Sociólogo pela Universidade Federal do Amazonas, 2011. E-mail: allison. andrade21@gmail.com

Maria Izabel de Medeiros Valle - Doutora em Sociologia pela Universidade Federal do Rio de Janeiro. Professora Associada da Universidade Federal do Amazonas. Atuando no PPG em Sociologia e no PPG Cultura e Sociedade. E-mail: izabelvalle@ufam.edu.br

\section{Resumo}

Este artigo discute as práticas de gestão do trabalho inspiradas no modelo japonês presentes na indústria de veículos sobre duas rodas localizada no Polo Industrial de Manaus. A pesquisa, realizada em 2009-2010, buscou identificar e analisar os instrumentos e as estratégias utilizadas pela empresa para promover a colaboração e a participação dos trabalhadores nos programas destinados à melhoria contínua. O estudo de caso revelou o New Honda Circle como o principal programa criado pela empresa para mobilizar e organizar os trabalhadores para a prática do trabalho em equipe e de caráter voluntário. Os cursos e treinamentos por ela realizados revelaram-se como estratégias empresariais importantes para o ensino-aprendizagem dos fundamentos filosóficos que orientam a sua política de pessoal.

\section{Palavras-chave}

Indústria japonesa. New Honda Circle. Polo Industrial de Manaus. Amazonia.

\begin{abstract}
This article discusses the work management practices inspired by the Japanese Model, within the two-wheeled vehicle industry located in Industrial Pole of Manaus. The research, which took place in 2009-2010, aimed at identifying and examining the instruments and strategies employed by the study's selected company to promote workers' participation and cooperation in programs towards continuous improvement. The case study indicated New Honda Circle as the main program created by the company to mobilize and gather the workers to work as a team and in a voluntary way. The courses and training held by the company have become important corporate strategies for the teaching-learning process of philosophical grounds that guides its personnel policy.
\end{abstract}

\section{Keywords}

Japanese Industry. New Honda Circle. Industrial Pole of Manaus. Amazon. 


\section{INTRODUÇÃO}

Esta pesquisa foi realizada com o objetivo de compreender a forma de realização do modelo japonês na indústria de veículos sobre duas rodas no Brasil. O estudo proposto está inserido no amplo campo de discussão sobre a emergência de novos paradigmas da produção industrial alternativos à produção em massa e a forma de sua transferibilidade para diferentes partes do mundo, distantes, portanto, dos lugares em que foram gestados e experimentados.

No levantamento bibliográfico realizado para a construção desta pesquisa, observamos a quase ausência de estudos e análise sobre as práticas de gestão inspiradas no modelo japonês em setores da atividade industrial brasileira com forte presença de empresas japonesas, como é o caso da indústria de veículos sobre duas rodas. Esta indústria encontra-se instalada na Zona Franca de Manaus, desde o início da década de 70 do século XX, gozando dos incentivos fiscais previstos pela regulamentação da ZFM. O conjunto das empresas deste segmento industrial constitui um dos polos estruturantes do Polo Industrial de Manaus e ocupa o segundo lugar em termos de volume de investimentos, faturamento e número de trabalhadores empregados, dentre os polos em que se distribui o PIM. Os Indicadores de desempenho do PIM para o ano de 2008 elaborados pela Suframa (2008) utilizados como base para o início da pesquisa apresentavam os seguintes dados para o polo de duas rodas: o faturamento ultrapassou os 13 bilhões de dólares, a produção de motocicletas foi da ordem de 1.516.444 unidades e o total da mão de obra empregada foi de 20.815 trabalhadores. Foi neste polo que se concentrou o interesse desta pesquisa.

Uma das primeiras fábricas a se instalar no setor industrial da ZFM, a empresa selecionada como locus da pesquisa, apresenta-se como a maior planta industrial da empresa produtora de veículos sobre duas rodas fora do Japão. De origem japonesa, tal empresa adotou, desde o início das suas operações, o modelo de gestão de produção e de pessoal baseado nos princípios ohnistas de organização da produção industrial. ${ }^{1}$ Nela, a investigação esteve orientada para a compreensão das práticas japonesas de gestão de pessoal, especificamente para os instrumentos utilizados pela empresa para estimular a participação dos trabalhadores nos programas destinados à melhoria contínua. Tais programas são constitutivos da gestão de pessoal que busca envolver os trabalhadores na identificação e solução de problemas relacionados à melhoria contínua.

1 No método Just in time, o princípio do trabalho em padrões flexíveis e tempos partilhados, a divisão funcional do trabalho, os sistemas Kaizen e Kanban são partes constitutivas do modelo de organização da produção industrial criado por Ohno (Cf. CORIAT, 1994). Além disso, a cooperação, a participação e o envolvimento dos trabalhadores na resolução de problemas apresentam-se como fundamentais ao funcionamento do modelo japonês. 
O termo japonês para designar melhoria contínua é kaizen. Para Imai (1988), "Kaizen significa melhoramento. Mais: significa melhoramento na vida pessoal, na vida doméstica, na vida social e na vida de trabalho. Quando aplicada para o local de trabalho, Kaizen significa melhoramentos contínuos envolvendo todo mundo - administradores e trabalhadores igualmente."

A empresa pesquisada possui seu próprio programa de melhoria contínua desde os anos 1980. Naquela década, o programa implantado recebeu a denominação de Círculo Moto Honda (CMH) e, em 2003, a denominação de New Honda Circle (NHC). São, portanto, estes programas que serão submetidos à análise para verificar de que forma ocorreu a transferibilidade do modelo japonês para a indústria de veículos de duas rodas e verificar os seus impactos sobre o trabalhador e sobre a sua jornada de trabalho.

Esta pesquisa, realizada entre 2009-2010, buscou inicialmente compreender os novos paradigmas da produção, em particular o "modelo japonês", para, através do trabalho de campo, identificar nas estratégias de gestão do trabalho utilizadas pela MHA, para fins de análise, aquelas orientadas pela filosofia da participação e que fundamentam a organização da empresa-matriz, a Honda Motor Co. Ltda., localizada no Japão e, por extensão, a sua subsidiária em Manaus.

Para efeito de compreensão e interpretação das estratégias empresarias utilizadas, foram entrevistados o staff que compõe o quadro técnico-gerencial diretamente relacionado à implementação das inovações organizacionais na empresa objeto da pesquisa. Desta forma, foram selecionados para fonte de informações a gerência de treinamento e desenvolvimento, a coordenação do programa de círculo de controle de qualidade e os instrutores encarregados da efetivação do conteúdo dos cursos e programas. As visitas à empresa, as entrevistas realizadas, as observações, os dados recolhidos, as fontes e documentos consultados foram procedimentos fundamentais para a realização do deste estudo.

\section{O MODELO JAPONÊS - BREVES CONSIDERAÇÕES}

O modelo japonês de produção industrial, apoiado nos princípios da flexibilidade é paradigmático da emergência de um novo modelo de produção industrial alternativo à produção em massa, adotado nos anos 1960 na indústria automobilística japonesa e que, nas décadas seguintes, expandiu-se em direção a outros segmentos industriais localizados fora do Japão.

As profundas mudanças nas "formas de produção, nos paradigmas tecnológicos, na divisão social do trabalho, na organização do trabalho e nas 
políticas de mão de obra, [simultaneamente] à introdução e difusão da automação microeletrônica na indústria" (HIRATA, 1993, p. 12), a partir de 1960, foram interpretadas por autores como Piore e Sabel (1984) e Kern e Shumann (1989), como constitutivas de um novo paradigma da produção industrial - a especialização flexível (PIORE; SABEL, 1984). Outros as identificaram com a emergência de um novo padrão de acumulação de capital fundado na flexibilidade (HARVEY, 1989). Outros autores consideraram as mudanças como expressão de um fordismo de novo tipo: neofordismo ou pós-fordismo ou, ainda, japonização do fordismo (WOOD, 1993).

Mas, em que consiste o modelo japonês ${ }^{2}$ ?

Wood (1993, p. 52-53) argumenta que "pelo menos no âmbito da literatura ocidental houve dois tipos principais de leitura do modelo de administração japonês. A que eles chamam de abordagem das relações humanas dá prioridade às práticas de pessoal; a outra - a abordagem da gestão da produção - enfatiza o pioneirismo do Japão ao introduzir o Just in Time (JIT) e, mais recentemente, o Círculo de Controle de Qualidade Total (CCQT).” Para o autor, tanto a interpretação da gestão da produção como a das relações humanas são "demasiado unilaterais", uma vez que o sistema Toyota, expressão mais bem acabada do modelo japonês, caracteriza-se pela combinação de procedimentos Just in Time e de elementos de relações humanas "que fornecem a base para o controle de qualidade total e o envolvimento dos trabalhadores na racionalização."

Coriat (1994) sintetiza na expressão "pensar pelo avesso", título de um de seus livros, aquilo que caracteriza o modelo japonês de organização da produção industrial: conjunto de princípios, métodos e técnicas construídos em oposição aos princípios organizativos do modelo fordista de produção. Nascido no Japão, sob inspiração de $\mathrm{Ohno}^{3}$ que o desenvolveu para a indústria automobilística Toyota no pós-Segunda Guerra Mundial, o modelo japonês caracteriza-se por um tipo de racionalização do trabalho orientada pela "des-especialização dos trabalhadores qualificados por meio da instalação de uma certa polivalência e plurifuncionalidade dos homens e das máquinas, concretizada pelas recomendações conjuntas de "liberalização" da produção, da "autonomação" e multifuncionalidade dos trabalhadores" (CORIAT, 1993, p. 81).

Durante os anos 1980 e, sobretudo, os de 1990, a expansão do modelo japonês para vários países do mundo intensificou os debates sobre o significado do novo paradigma e estimulou estudos e pesquisas em vários países sobre os

\footnotetext{
2 Não há unanimidade quanto a essa noção, entre os estudiosos do modelo japonês. A respeito das definições possíveis de modelos japoneses, consultar Hirata (1993).

3 Daí as expressões ohnismo ou toyotismo para designar o modelo japonês.
} 
diferentes e diversos aspectos da transferibilidade do modelo para contextos econômicos, sociais e culturais distintos.

No Brasil, o debate sobre os novos paradigmas ganhou impulso no final da década de 1980 com os estudos e pesquisas pioneiros realizados na indústria automobilística brasileira por Hirata (1983) e Humphrey (1995) e, na indústria eletrônica, por Salerno (1985). Nos anos 1990, estudos e pesquisas sobre o tema foram realizados na indústria metal-mecânica do Rio de Janeiro por Ruas, Antunes e Roese (1993). 'Tais estudos revelaram as formas de adaptação do modelo à realidade brasileira e os seus impactos sobre a organização do processo de produção, as formas de gestão e as relações de trabalho.

Formas de gestão de pessoal baseadas nos princípios do modelo japonês - participação e qualidade -, encontram-se presentes na indústria eletroeletrônica, conforme observado por Valle (2007) e por Moraes (2010), cujos estudos ressaltaram a "participação" e a "colaboração" como essenciais à gestão baseada na cultura da qualidade e da "valorização" do trabalhador. A ausência de estudos sobre o tema na indústria de veículos sobre duas rodas estimulou a pesquisa neste segmento industrial.

\section{A INDÚSTRIA DE VEÍCULOS SOBRE DUAS RODAS NO BRASIL E O LUGAR DA MOTO HONDA DA AMAZÔNIA (MHA)}

A indústria de veículos sobre duas rodas no Brasil está localizada em Manaus, na região norte do país, cidade-sede da Zona Franca Brasileira desde 1967. A capital do estado do Amazonas abriga os investimentos estrangeiros realizados pelos grandes produtores mundiais de motocicletas e bicicletas que, atraídos pela condição de "porto livre" da cidade, nela instalaram suas plantas industriais para a realização da produção destinada ao abastecimento do mercado nacional.

Entre os polos industriais da Zona Franca de Manaus (ZFM), aquele que reúne as indústrias de veículo sobre duas rodas apresenta-se como "polo estruturante" do Polo Industrial de Manaus, ao ocupar a vice-liderança ${ }^{4}$ no conjunto dos polos, em volume de investimentos, faturamento e geração de emprego. O desempenho do setor, conforme os indicadores econômicos (Quadros 1,2,3), aponta para a sua importância no conjunto da economia amazonense, que tem no PIM o seu principal sustentáculo.

O polo eletroeletrônico ocupa historicamente a liderança no Polo Industrial de Manaus. 


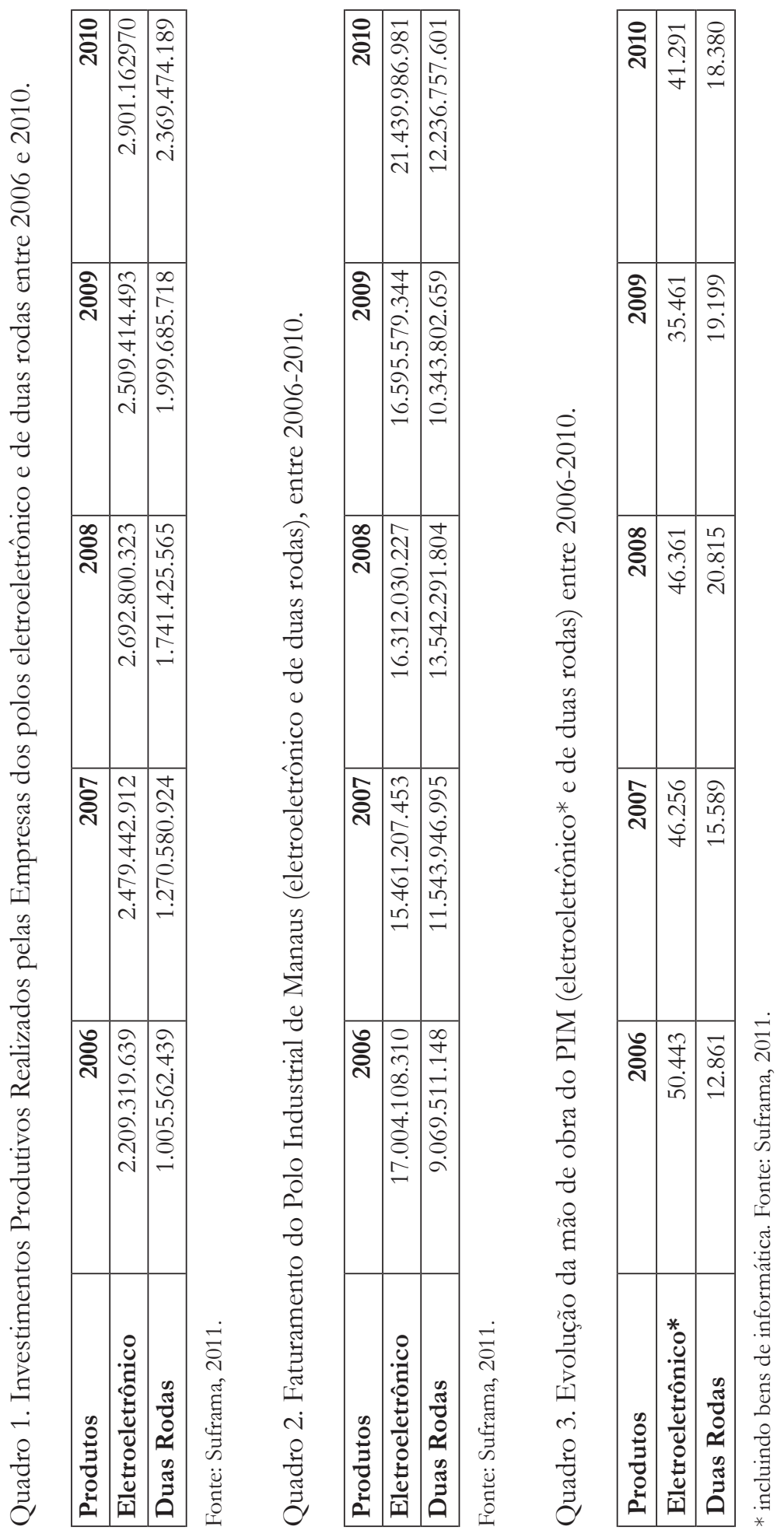


No polo de duas rodas ${ }^{5}$ concentram-se os grandes produtores mundiais de motocicletas e bicicletas como Honda, Yamaha, Suzuki, Kawasaki (Japão), Harley-Davidson (EUA), Moto Traxx, Zongshen e Haobao (China). Aos fabricantes das marcas 100\% chinesas, somam-se as empresas brasileiras Dafra e Sundown, que utilizam tecnologia chinesa. Na liderança deste segmento industrial encontra-se a Honda, com os chineses pretendendo aumentar a sua participação nas vendas de moto no mercado nacional com a estratégia de preços mais competitivos e ampla rede de concessionárias espalhadas pelo país.

A produção de veículos sobre duas rodas no Brasil, notadamente motocicletas e bicicletas, está historicamente ligada à instalação de uma unidade produtiva da Honda em Manaus.

Primeira empresa do setor de duas rodas a instalar-se na zona franca, a Honda dirigiu seus investimentos para Manaus no ano de 1975 com o propósito de produzir motocicletas para o mercado consumidor brasileiro. Sob a denominação de Moto Honda da Amazônia (MHA), a empresa construiu sua planta industrial na área destinada pela Superintendência da Zona Franca de Manaus (Suframa), órgão federal responsável pela administração da ZFM, aos grandes projetos industriais. Sua localização em Manaus deve-se a um conjunto de fatores, destacando-se, entre eles, a política de restrição às importações do governo brasileiro nos anos iniciais da década de 1970, para fazer frente à crise mundial provocada pela alta no preço do petróleo, os atrativos oferecidos pela área de livre comércio situada em Manaus, sobretudo os incentivos fiscais e as características do mercado de trabalho da mão de obra local.

\subsection{Chegada da Honda ao Brasil e a criação da MHA em Manaus}

Criada em 1948 no Japão, a Honda expandiu-se rapidamente pelo mundo, sobretudo nas décadas de 1960 e 1970: em 1959, a Honda chegou aos Estados Unidos com a denominação de American Honda Motor dos Estados Unidos; em 1961, na Alemanha; em 1969, na Austrália e Canadá; em 1971, no Brasil e México; em 1973, na Indonésia e, em 1974, no Peru (HONDA, 1997, p.24).

\footnotetext{
No polo de duas rodas encontram-se instaladas em torno de 13 empresas: Caloi Norte S.A; CR Zongshen Fabricadora de Veículos S.A; Prince Bike Norte Ltda.; Kawasaki Motores do Brasil Ltda.; J. Toledo da Amazônia; Bramont Montadora Indústria e Comércio Ltda.; Dafra da Amazônia Indústria e Comércio de motocicletas Ltda.; Moto Traxx da Amazônia; Garinni Motors Indústria de Veículos Ltda.; Haobao Motor do Brasil Ltda.; Harley - Davidson do Brasil Ltda.; Yamaha Motor da Amazônia Ltda.; Moto Honda da Amazônia Ltda.
} 
A chegada da Honda ao Brasil na década de 1970 foi impulsionada pela política de importações do governo brasileiro e, também, pela conquista de mercado, conforme se pode depreender da leitura do texto abaixo:

Até então havia a Lambretta barulhenta, soltava muita fumaça, mas era o que a indústria nacional produzia. As importações estavam proibidas. Até a segunda metade da década de 1960 praticamente não existia mercado para motocicletas no Brasil. Os registros de licenciamento indicavam que em 1968 havia no país inteiro, apenas 3.863 motocicletas, em contraste com os mais de 2 milhões atuais. Além das nacionais, circulavam algumas italianas, inglesas, e norte-americanas adquiridas em períodos curtos de liberação de compra de produtos estrangeiros. Em 1968 o governo autorizou as importações de modo mais duradouro - a proibição viria a ser novamente imposta sete anos mais tarde. As alíquotas eram muito elevadas: 105\%. Mas a oportunidade estava criada. O esforço de conquista do mercado brasileiro iria ter início (HONDA, 1997, p. 28).

No ano de 1971 foi inaugurada na cidade de São Paulo a Honda Motor do Brasil Ltda., tendo como principal objetivo importar e distribuir os produtos da empresa no território brasileiro. O início da primeira fase dessas importações ocorreu em 1973. No ano seguinte, fazendo planos para instalar uma fábrica no Brasil, a Honda efetuou a compra de um terreno de 1,5 milhão de metros quadrados em Sumaré, no interior do estado de São Paulo, para a fabricação de motos (HONDA, 1997). No entanto, a crise mundial do petróleo na primeira metade dos anos 1970 fez com que o governo brasileiro de imediato restringisse as importações, o que afetou diretamente os interesses de importação da Honda no Brasil: "O resultado foi que seu volume de importações caiu pela metade, de 24 mil unidades em 1974 para 11 mil em 1975” (HONDA, 1997, p.42).

Em meados da década de 70, pressionada pelas restrições do governo brasileiro à importação, a Honda adotou novas estratégias visando o seu crescimento e consolidação no mercado nacional. Entre elas, destaca-se a opção de instalação de uma unidade produtiva no coração da Amazônia, na cidade de Manaus, aonde o governo brasileiro instalara uma área de livre comércio em 1967. Entre as inúmeras vantagens para a instalação da empresa japonesa na capital do Amazonas estavam os incentivos fiscais, as facilidades para a importação e o perfil da mão de obra local que, desprovida de experiência e qualificação, favorecia o treinamento orientado pelos princípios filosóficos e práticas de gestão característicos da empresa (HONDA, 1997). Assim é que a Honda inaugurou, em 1975, em Manaus, sua nova fábrica com a denominação Moto Honda da Amazônia S./A. e deu início à produção de veículos sobre duas rodas. Um ano após a inauguração, a empresa passou a ser denominada Moto Honda da Amazônia Ltda. (MHA). 
As dificuldades enfrentadas pela empresa em Manaus, decorrentes da distância geográfica da região amazônica em relação a outros centros industriais brasileiros e das condições precárias da infraestrutura de transporte e de comunicações, conduziram a MHA a se tornar a empresa "mais verticalizada entre as inúmeras empresas do grupo espalhadas pelo mundo" (HONDA, 1997). A solução encontrada pela empresa para a superação da dificuldade de fornecedores locais foi de duas ordens: transferência de tecnologia japonesa para o Brasil e constituição de parcerias com fornecedores nacionais e/ou atração de seus antigos fornecedores japoneses, como o caso da Showa (fábrica de amortecedores), para Manaus. Frente às dificuldades em encontrar fornecedores nacionais que dispusessem de tecnologia apropriada para fabricar peças altamente sofisticadas e segundo o padrão de qualidade previamente definido pela empresa, a MHA decidiu pela produção de suas próprias peças tais como assentos, tanque de gasolina, cabeçotes, aros e outros, o que resultou na criação, em 1985, de uma nova planta industrial: a Honda Componentes da Amazônia Ltda. (HONDA, 1997).

Durante o decorrer das décadas de 1980 e 1990, a MHA ingressou em um período de reestruturação em sua produção e gestão. Buscando alternativas à crescente subida internacional no preço dos combustíveis, resultante da crise mundial do petróleo, a Moto Honda da Amazônia lançou, em 1981, a primeira motocicleta do mundo movida a álcool. No entanto, com a queda do Produto Interno Bruto (PIB) brasileiro em 1983, o aumento da inflação e o aumento do índice da taxa de desemprego, o consumo de motocicletas no mercado nacional começou a apresentar uma acentuada queda.

Uma das medidas tomadas pela empresa para reanimar o crescimento da produção e de vendas foi o estabelecimento, em 1985, de uma filial da Moto Honda da Amazônia em São Paulo. Esta filial contribuiu para a redução de algumas despesas administrativas e também custos fiscais, pois dentre as responsabilidades que lhe foram atribuídas destacavam-se: “[...] Operações de planejamento mercadológico, comercialização de produtos acabados e peças de reposição, serviços pós-vendas, logística, desenvolvimento de produto, suprimento de componentes, comunicação e informatização" (HONDA, 1997, p. 66).

Outras medidas adotadas pela empresa como alternativas à crise econômica brasileira foram a criação do Consórcio Nacional Honda (CNH), em 1981, e o início das exportações para outros países do continente americano, África, Europa e Oriente Médio.

Ainda durante o período de crise na economia brasileira, a MHA começou a implantar práticas de gestão japonesas já utilizadas em sua matriz no Japão, com a intenção de garantir o crescimento da empresa no mercado nacional. Algumas dessas práticas são assim sumarizadas no informativo da empresa: 
[...] CMH - Círculo Moto Honda ou Círculo de controle de qualidade; Campanha Lar (Limpeza, Arrumação, Revisão); ou 5 S. [...] CDD, Comissão de Detecção de Defeitos de peças e conjuntos; SBP, sigla de Software for Best Position, quer dizer, promover melhorias no local de trabalho, visando acabar com a ociosidade; PPS significa Plano Permanente de Sugestões; MPT, Manutenção Produtiva Total, executada pelo próprio operador da máquina; KYT, Treinamento de Prevenção ao Perigo, destinado a estimular o funcionário a tomar medidas preventivas (HONDA, 1997, p. 72).

Tais práticas de gestão estavam em vigência no momento de realização da pesquisa e todas elas visavam a contínua melhoria na qualidade dos produtos e de seus processos de produção. Essa constante preocupação com padrões de qualidade rendeu à Moto Honda da Amazônia certificações de qualidade, como a ISO 9002, em 1995.

\section{A MOTO HONDA DA AMAZÔNIA E A FILOSOFIA HONDA}

Desde sua inauguração em 1975, a Moto Honda da Amazônia (MHA) passou por grande expansão física, chegando a reunir no mesmo complexo fabril a Honda da Amazônia (HDA), a Honda Componentes da Amazônia (HCA) e a Honda Tecnologia da Amazônia (HTA).

A HDA, a HCA e a HTA juntas dispõem de um terreno de $661.000 \mathrm{~m}^{2}$, com um total de $193.000 \mathrm{~m}^{2}$ de área construída. Entre elas, opera-se a seguinte divisão de tarefas: a produção e venda de motocicletas é feita na HDA; a fabricação de peças para motocicletas está reservada à HCA; e na HTA encontra-se a parte de ferramentas e produtos de força (MELO, 2010). Figura 1.

Durante a realização do trabalho de campo, pôde-se perceber a existência de um pequeno espaço na empresa reservado ao treinamento de pessoal. Esta área, destinada ao Centro de Treinamento (CT), possui salas para a realização de cursos como Filosofia Honda, 5S, Curso J, Kaizen, Kanban, Brigada de incêndio, Metrologia básica; outros cursos são ministrados na sala de mecânica dentro do CT. Nesta sala encontram-se algumas motocicletas de modelos diferentes utilizadas para estudo e treinamentos e, ainda, um grande conjunto de ferramentas úteis para cada modelo. Para toda a empresa de Manaus, no Centro de Treinamento, há apenas um instrutor de mecânica que ministra treinamentos para os mecânicos na empresa e, segundo o próprio instrutor entrevistado, alguns cursos são introduzidos e ministrados em consonância com os problemas encontrados em cada setor. 
Figura 1. Subdivisão dos setores da MHA.

\section{Moto Honda da Amazônia Ltda.}

HONDA

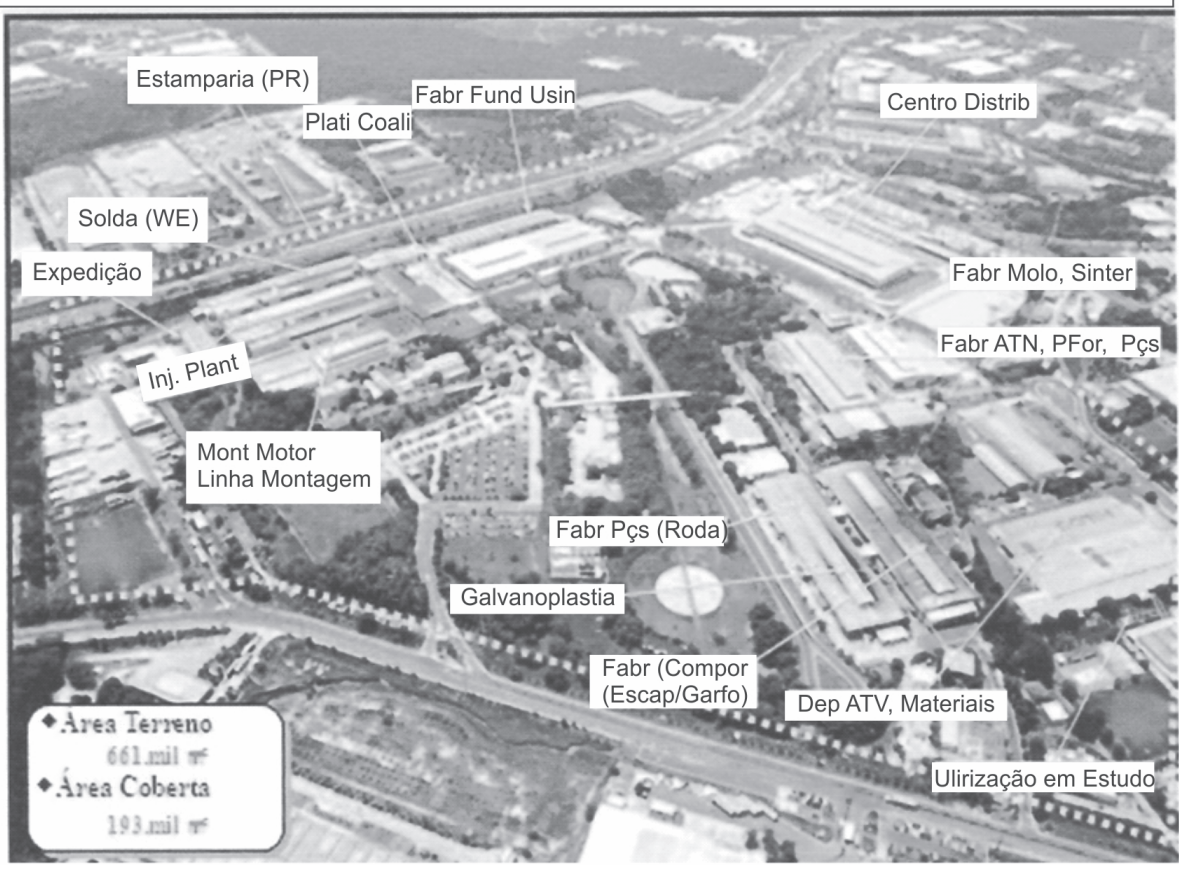

Fonte: Melo, 2010.

Segundo as informações coletadas, a MHA ocupa os espaços aonde anteriormente localizavam-se duas outras empresas. Esses espaços deram lugar ao Centro de Treinamento, a uma pequena biblioteca destinada aos "colaboradores", a um refeitório e aos galpões para produção de quadriciclos e outros.

Devido ao alto grau de verticalização desta empresa e à dimensão do seu espaço físico, toda movimentação dentro dela tanto de "colaboradores" como de visitantes é feita através de uma condução que tem como única finalidade a locomoção de pessoas entre os seus diversos setores da empresa.

Este transporte interno faz parte de um conjunto de empresas terceirizadas contratadas pela MHA, totalizando 40 empresas e 1.500 trabalhadores. Estas empresas encontram-se dentro da MHA, tendo seus serviços "distribuídos entre limpeza, lavanderia, transportes internos, segurança, alimentação, jardinagem, assim como serviços relacionados a sistemas informacionais e administrativos da empresa" (MELO, 2010, p. 27).

6 Colaboradores são todos os trabalhadores que direta ou indiretamente participam das atividades na MHA. Essa expressão é utilizada por todos os membros da empresa. 
Além dos 1.500 trabalhadores contratados como prestadores de serviços, a Moto Honda da Amazônia dispunha, em 2009, de um quadro de trabalhadores com cerca de 19.000 trabalhadores, submetidos a quatro tipos diferenciados de contratos de trabalho: temporário, tempo de experiência, tempo indeterminado e estágios (MELO, 2010).

A mão de obra selecionada pela MHA, de acordo com Melo (2010, p. 37), cresceu substancialmente entre os anos de 1990 e 2008: em 1990, a MHA empregava diretamente cerca de 2.126 trabalhadores e, após 18 anos, mais de 20 mil. A maior concentração de trabalhadores encontrava-se na área da produção conhecida como Honda da Amazônia (HDA).

Todos os trabalhadores da MHA são treinados para operarem segundo os padrões de qualidade estabelecidos pela própria empresa, com base nos princípios da filosofia Honda.

\subsection{A Filosofia Honda}

A preocupação com a qualidade levou as empresas japonesas à exigência de um nível muito mais profundo de comprometimento dos seus trabalhadores com a empresa, do que qualquer outra do mundo industrial. Garvin (1992, p. 239) afirma que esse comprometimento era profundamente arraigado e amplamente difundido entre os trabalhadores, de uma forma bem clara: "Este era visível em qualquer lugar: nas declarações da filosofia da companhia, nos manuais de políticas, murais e quadros de avisos." Neste sentido, a filosofia da empresa estudada tem servido de grande base para a sua manutenção e desempenho em um cenário marcadamente competitivo.

A Filosofia Honda é, segundo o livreto de bolso Filosofia Honda, publicado pela Honda Motor Co. Ltda. em 1998, “o legado mais valioso deixado pelos fundadores Soichiro Honda e Takeo Fujisawa"7.

Na MHA, esta filosofia é transmitida a todos os seus "colaboradores", diretamente através do curso Filosofia Honda, ministrado no Centro de Treinamento pelos instrutores da própria empresa. No ato da conclusão do curso, os "colaboradores" recebem um livreto de bolso e um caderno sobre a filosofia.

Trecho retirado da introdução do livro de bolso "Filosofia Honda" (1998), que mais precisamente informa na sua página inicial: "A força motriz por trás do crescimento da Honda foi a liderança de seus fundadores - Soichiro Honda e Takeo Fujisawa. O legado mais valioso que nossos fundadores deram para nossa companhia é a filosofia. A filosofia Honda continuará a servir como base de nossas ações comerciais e decisões diárias para todas as empresas e colaboradores do grupo Honda". 
Para a Honda, a compreensão, o respeito e o compartilhamento de sua filosofia por parte de todos os seus "colaboradores" são de fundamental importância e não devem se limitar a palavras ou se restringir à fábrica, mas traduzir-se em ação, no intuito de expandir a cultura corporativa e trazer novos valores à sociedade.

A Filosofia Honda está dividida em três pontos centrais: Crenças Fundamentais; Princípio da Honda; e Política de Gestão da Honda. Antes de apresentarmos os pontos centrais da Filosofia Honda, julgamos necessário uma breve introdução sobre sua formulação, para melhor compreendermos o sentido a ela imprimido pelos seus fundadores.

Em 1953, o fundador da Honda, Sr. Soichiro Honda, buscava oportunidades para superar seus concorrentes, anunciando no periódico mensal da Honda a "busca por 120\% de qualidade". Segundo informação do instrutor Denisval" , "o Sr. Soichiro Honda dizia que os produtos que possuíssem qualidade não encontrariam fronteiras". O senhor Honda possuía uma enorme preocupação com a qualidade, visando o lucro para sua empresa através da satisfação de seus clientes. Para ele, as pessoas sempre deviam estar em primeiro lugar, sendo, portanto, o foco principal da empresa.

O fundador, ainda de acordo com o instrutor, dava extrema importância ao bem-estar dos seus "colaboradores", entendendo que os mesmos passavam a maior parte de seu tempo dentro da empresa. Sendo assim, se estes colaboradores não se sentissem bem na empresa, de forma alguma poderiam ter alegria e satisfação para desempenhar um trabalho de qualidade.

Neste sentido, a Honda, irá promover uma política de salários e benefícios diferenciada de forma a promover o atendimento da satisfação dos seus "colaboradores". O instrutor informa que no polo de duas rodas situado em Manaus, a MHA é uma das empresas que oferecem um dos maiores salários, oferecendo benefícios não somente para o "colaborador", mas também para sua família. Sobre esse ponto, Denisval comenta:

Esse pagamento... é porque a Honda pensa também na família do colaborador; ele tem tudo isso aqui dentro, mas e a família dele? Como é que tá? Aqui dentro ele tem uma farmácia, ele tem serviço odontológico, serviço médico; se ele tiver passando mal, ele vai lá rapidinho no serviço médico; se for algo grave, ele tem prioridade no atendimento, ele é atendido; se não puder, os médicos daqui encaminham ele para a Unimed. Então, a Honda busca também amparar a família deste colaborador, baseada nesta filosofia, justamente estando preocupada com a família deste colaborador, fazendo com que ele fique mais à vontade (Denisval, Instrutor Honda, 2010).

8 As informações foram colhidas na empresa durante os dias em que foram ministradas palestras por quatro instrutores da MHA no Centro de Treinamento da empresa. 
Segundo Denisval, os benefícios têm impacto na vida do "colaborador" e de quem é dependente dele. E esses benefícios são frutos, de acordo com o mesmo instrutor, da Filosofia Honda.

\subsection{Crenças fundamentais: o respeito pelo indivíduo e as três alegrias}

Para a Honda, essas Crenças Fundamentais são consideradas a "missão" da empresa; a sua razão de ser. Tais Crenças desdobram-se em princípios concebidos como "O Respeito pelo Indivíduo e As Três Alegrias".

O Respeito pelo Indivíduo refere-se não somente aos que trabalham como contratados pela empresa, mas a todos aqueles que de alguma forma contribuem para o seu funcionamento e crescimento. Sendo assim, entre estes indivíduos incluem-se os fornecedores, os terceirizados, os clientes, os "colaboradores", a família dos "colaboradores", os vendedores etc. E tais indivíduos são tratados como peças de extrema importância para a empresa. Conforme afirma Denisval:

Esse respeito pelo indivíduo traz como fundamento de que essas pessoas são jogadores principais... são jogadores principais da empresa que não podem faltar. Se eu tirar um deles, a empresa vai ficar incompleta. Se eu tirar um terceiro, que é uma empresa terceirizada que fazem a limpeza dos banheiros nossos, a empresa fica incompleta porque o colaborador vai usar o banheiro lá onde é usado por muitas pessoas lá da produção e ele chega lá e já chega e encontra sujo porque falta consciência de alguns colaboradores nossos e... aí... você imagina ele ir utilizar o banheiro se não tiver esse cuidado com o banheiro e essa limpeza, ele vai ficar triste, vai ficar decepcionado, alguns não vão nem usar o banheiro, com medo de adquirir alguma enfermidade, alguma doença (Denisval, Instrutor Honda, 2010).

Dentro do princípio de Respeito pelo Indivíduo existem três conceitos principais: Iniciativa, Igualdade e Confiança.

A Iniciativa parte da ideia de que cada "colaborador" deve "pensar de forma criativa e agir por iniciativa e opinião próprias", sempre tendo em vista as consequências de suas atitudes, boas ou ruins. Cada "colaborador" deve ter em si o desejo constante de crescer e, para isso, é necessário que ele tenha iniciativa de aprender, especializar-se e buscar meios que possam levá-lo a atingir objetivos cada vez maiores. Segundo Denisval, essa iniciativa é resultado de pessoas que têm força de vontade, que têm ambição de crescer e não se colocar numa zona de conforto.

Uma das oportunidades que a empresa julga oferecer a este "colaborador" para mostrar sua iniciativa é o New Honda Circle, pois através deste programa a empresa afirma que os colaboradores unidos em um pequeno grupo podem trabalhar para criar um local de trabalho melhor, melhorando a qualidade do seu trabalho por meio da iniciativa própria. 
No que se refere à Igualdade, a Honda, de acordo com o instrutor, procura sempre gerar oportunidades para todos, de maneira igualitária. Sobre isso, Denisval apresenta o seguinte exemplo:

Tem uma vaga para líder de controle de qualidade (LCQ) e aí essa vaga... é claro, a Honda procura trabalhar só mesmo e... ela procura limitar ali as áreas que podem concorrer; se for na de usinagem, então ela abre um concurso interno dentro da área de usinagem pra que possam concorrer àquela vaga. Quem pode participar? Qualquer pessoa que esteja abaixo do nível de LCQ ou dentro do nível de LCQ. Então ele vai lá, ele participa, então é uma oportunidade dada de igual modo pra todos, porém, quem vai ficar com a vaga são aquelas pessoas [...] até pra contemplar as que tiveram iniciativa; são aquelas pessoas que realmente têm atitude; são aquelas pessoas que têm a iniciativa, a força de vontade, que estudaram mais, que pesquisaram mais, que se empenharam mais em conhecer mais processos, mais as etapas dos fluxos dos processos, a questão da qualidade mesmo, saber conhecer os princípios da qualidade da Honda. Então isso daí as pessoas beneficiadas... é... nessa questão do conceito da igualdade serão pessoas que realmente se esforçaram mais (Denisval, instrutor Honda, 2010).

A Confiança é o terceiro ponto das Crenças Fundamentais. De acordo com o livreto de bolso da Filosofia Honda, a confiança "é obtida quando reconhecemos os outros como indivíduos, ajudamos em áreas em que as pessoas têm dificuldade, aceitamos ajuda nas que falhamos, compartilhamos nosso conhecimento e assumimos nossas responsabilidades" (HONDA, 1998, p.7). Ainda sobre a questão da igualdade, afirma o Sr. Soichiro Honda que:

Se houver qualquer pessoa em nossa empresa que julgue o outro com base apenas no fato dessa pessoa ter ou não dinheiro, e a discrimine ou seja injusta, então creio que quem fez este julgamento de mérito não preza a independência e a liberdade. É por isso que peço a cada colaborador da empresa que sempre trate os outros como iguais, em todas as situações. Por favor, respeitem este princípio básico (ESPAÇO HONDA, 2009. p 13)

Com isso, podemos entender que Confiança nesta Filosofia é fator indispensável dentro do espaço das relações de trabalho, quer seja entre liderados, quer seja entre líderes, quer seja entre líderes e liderados, independente da posição hierárquica.

A compreensão dessas Crenças Fundamentais será de grande importância para a análise do programa New Honda Circle, objeto deste estudo.

O segundo princípio da Filosofia Honda é o que se refere às Três Alegrias. Segundo o instrutor de treinamento, para o bom andamento das relações comerciais é de fundamental importância, para a Honda, que existam três Alegrias: Alegria de Comprar, Alegria de Vender e Alegria de Criar. 
A primeira está direcionada ao cliente. Como já foi dito, para a Honda, o principal foco da empresa é o indivíduo, incluindo o cliente. Este cliente deve estar satisfeito com o produto por ele adquirido. Os "colaboradores" da Honda trabalham "de olho" no cliente, ou seja, de olho nas expectativas e necessidades desse cliente. Para a empresa, o cliente deve ter suas expectativas alcançadas e superadas. Em outras palavras, o cliente deve obter a satisfação de suas necessidades nos produtos desenvolvidos pela MHA; se ele se decepcionar, já não haverá mais cliente para a empresa.

A “Alegria de Vender" é parte de todos os concessionários; estes devem ter o prazer de ser um representante da marca Honda, sentirem-se bem em estar vendendo um produto produzido por esta empresa, sabendo de suas vantagens, tendo certeza de que está trabalhando com um produto de qualidade, que não trará problemas com os clientes.

Em uma das visitas feitas à empresa MHA, o Supervisor de Treinamento e Desenvolvimento informou-nos que na semana anterior ele havia recebido um grupo de 70 funcionários de uma concessionária de São Paulo e afirmou que os levou para fazer um passeio em toda a fábrica. Tal atitude despertou entre os visitantes, segundo ele, um profundo sentimento de alegria. O supervisor afirmou que tinha a certeza de que quando aquele grupo retornasse a São Paulo e voltasse a trabalhar, ou seja, vender, ele o faria com o máximo de empolgação e alegria, motivando e contagiando os seus clientes, posto que pode difundir junto ao seu público que o produto que irá adquirir é realmente de boa qualidade, e que viram isso pessoalmente durante visita à fábrica de Manaus.

Em terceiro, encontra-se a "Alegria de Criar", que está ligada diretamente aos "colaboradores", à área interna da empresa. É de fundamental importância para esta empresa que todos os seus "colaboradores" tenham grande satisfação em estar continuamente criando: terem criatividade para produzir novos produtos que atendam cada vez mais as necessidades e expectativas de seus clientes. Além disso, este "colaborador" deve estar contente em fazer parte do grupo Honda, sabendo que é um grupo de qualidade e portador de um "bom" nome junto ao mercado. Para isso, a empresa procura oferecer para os seus "colaboradores" o melhor ambiente de trabalho possível.

É importante salientar que o conhecimento destas Três Alegrias está presente em todos os programas de melhorias desenvolvidos pela empresa, uma vez que todas elas estão dirigidas para as pessoas. Assim, vale ressaltar que no desenvolvimento do NHC, a produção estará centrada nas Alegrias de Comprar, Vender e Criar. 


\subsection{O Princípio Honda: a Visão}

Em 1956, a Honda lançou o Princípio Honda em Japonês. Esse princípio é o que esta empresa tem como sua visão: olhando para o cliente, a empresa procura descobrir suas necessidades e assim produzir um produto para ele. Este princípio foi revisado em 1998, ganhando a seguinte redação: “Em um espírito global dedicamo-nos a oferecer produtos da mais alta qualidade a um preço justo, para a satisfação de nossos clientes em todo o mundo" (HONDA, 1998, p.13).

Segundo o instrutor Denisval, ao falar em "espírito global", a Honda mostra a sua preocupação em oferecer os melhores padrões de qualidade existentes no mundo. É em razão disso, comentou o instrutor, que a Honda possui seu próprio centro de tecnologia, onde são realizadas as pesquisas que os levam a estar sempre à frente de seus concorrentes. Ele também informou que todo o maquinário atualmente existente na MHA é originário do Japão, e que o "espírito global” leva a Honda a ter cuidado com a questão ambiental e fornece um exemplo:

[...] Então, antes nós tínhamos aqui o escapamento cromado e hoje as nossas motocicletas já não saem mais com o escapamento cromado porque o cromo gera um impacto ambiental muito grande e a Honda pra reduzir isso trocou o processo galvânico que é o que trabalha com cromo pelo processo de pintura a alta temperatura. O processo de pintura a alta temperatura deixou de poluir? Não, mas ela reduziu o impacto ambiental (Denisval, Intrutor Honda, 2010).

O livreto de bolso Filosofia Honda traz à página 15 o enunciado de que os clientes são a garantia da existência da Honda, pois são eles que compram os seus produtos. Isso deve despertar em cada "colaborador" o interesse em fazer o máximo para satisfazer as necessidades e expectativas dos clientes em todo o mundo. E essa satisfação do cliente para a Honda consiste também em estar atento para se antecipar a toda e qualquer forma de mudança cultural ou social que afetem o estilo de vida destes clientes, mudando, assim, suas necessidades.

Para a empresa, "preço justo": o "preço justo" não significa preço baixo ou barato, mas é o resultado do olhar do cliente sobre o produto Honda e sua correlação entre custo-benefício. O cliente saberá avaliar se tal produto atenderá as suas necessidades e se o investimento irá valer a pena.

A palavra "dedicamo-nos" encontra-se presente no Princípio da Honda porque a empresa preza a união de todos os seus "colaboradores" para alcançar um objetivo comum. E para a Honda "é por meio da dedicação plena que se obtém a verdadeira alegria no trabalho" (HONDA, 1998. p. 17). 


\subsection{A Política de Gestão da Honda}

Esta política consiste em padrões estabelecidos pela empresa e que devem ser utilizados diariamente em todos os processos produtivos e administrativos. Estes padrões foram estabelecidos pelo fundador da Honda, a partir de cinco princípios: Manter sempre o sonho e o espírito jovem; Valorizar as teorias, as ideias e o tempo; Amar o seu trabalho e valorizar a comunicação; Criar constantemente um fluxo de trabalho harmonioso; e Ter sempre em mente os valores da pesquisa e da perseverança.

O "espírito jovem" diz respeito aos sonhos, à visão que se estabelece para a vida. No caso da Honda, é a visão voltada para os negócios. Ter esse espírito jovem é ter grandes desejos e não ter medo de enfrentar novos desafios.

A MHA orienta os "colaboradores" a não desprezarem as teorias, ideias e o tempo. É importante para ela que os "colaboradores" busquem em tais coisas aquilo que pode ser útil. É preciso que os "colaboradores" tenham prazer no que fazem e, para isso, é necessário que eles amem o seu trabalho e valorizem a comunicação dentro da empresa. A Honda acredita que quanto mais o "colaborador" amar o seu trabalho, mais rapidamente ele mergulhará dentro dos processos.

Sobre a criação de um fluxo de trabalho harmonioso, Denisval comenta que o "processo que o colaborador desenvolve deve ser a área mais gostosa da fábrica"; para isso, ele tem a liberdade para criar uma melhor forma para desenvolver seu trabalho.

Em quinto lugar estão os valores da pesquisa e da perseverança que o Grupo Honda espera que seus "colaboradores" mantenham sempre vivos. Para a empresa, o "colaborador" nunca deve estagnar; ao contrário, deve estar sempre em busca de se aperfeiçoar. A afirmação de Denisval nos ajuda a entender melhor esta questão:

[...] Então quando eu paro... quando eu paro em determinado limite e eu acredito que aquilo ali pra mim tá bom, a partir daquele momento que eu parei e começa o meu declínio; eu começo a cair ali, porque o conhecimento, as informações vão continuar surgindo e eu busco então... eu paro de buscar esse conhecimento e o que acontece comigo? Eu sou desvalorizado no meu ambiente de trabalho, no mercado competitivo e na minha especialização. Tem pessoas que se limitaram (Denisval, Instrutor Honda, 2010).

Este ponto é o que mais se destaca no New Honda Circle, pois aqui estão concentrados três princípios que são usados como uma grande ferramenta para a pesquisa e solução de problemas na empresa. É o chamado Princípio das três Realidades: Genba (lugar de ocorrência do fato), Genbtsu (objeto/situação real) e Genjitsu (ser realista). 
Durante a ocorrência de um eventual problema, antes de solucioná-lo o "colaborador" nele envolvido deve verificar os fatos, deslocando-se para o local do ocorrido, seja na linha de montagem, seja no setor de administração ou em outro lugar. Durante a verificação diretamente no local do ocorrido, ele deverá analisar o objeto ou situação através de sua visualização ou entrando em contato direto com os elementos reais. Após sua análise, ele deverá tomar decisões realistas, baseado nas informações por ele coletadas através do que foi presenciado no local.

\section{O NEW HONDA CIRCLE (NHC)}

Estamos aqui diante do objeto central desta pesquisa: o New Honda Circle, um programa de melhoria desenvolvido pela MHA, caracterizado como um Círculo de Controle da Qualidade (CCQ). Na pesquisa realizada junto à Moto Honda da Amazônia, durante as visitas à empresa colhemos informações sobre o histórico deste CCQ e suas características, assim como sobre sua forma de implantação e desenvolvimento.

O New Honda Circle (NHC) foi implantado em 1980 nas Unidades de Manaus, sob a denominação Círculo Moto Honda $(\mathrm{CMH})$, logo após o retorno do Sr. Horácio (diretor da Honda Automóveis Brasil), do Japão, país aonde este CCQ já existia e estava consolidado. De acordo com o informativo da Honda (2008),

Horácio Natsumeda foi o responsável pela introdução do NHC no Brasil, em 1980, na fábrica de Manaus. No primeiro ano, os colaboradores não conheciam a metodologia das ferramentas da Qualidade e ele mesmo treinou os participantes dos 10 grupos inscritos. Foi ele também quem acompanhou o primeiro grupo de Manaus a se apresentar no Japão (HONDA, 2008. p. 2).

No ano de sua implantação, este Círculo iniciou com apenas 10 grupos formados. Naquele momento, este programa era uma grande novidade, posto que se apoiava em uma filosofia até então desconhecida pelos trabalhadores. Pouco a pouco, o CMH foi tomando espaço dentro da fábrica com os "colaboradores" sendo instruídos sobre as sete ferramentas da qualidade. No segundo ano, segundo informações do instrutor Gomes, que participou do primeiro Círculo, em 1981, o número de participantes no programa dobrou. Já em 2009, o número de grupos formados foi da ordem de 1422 (HONDA, 2009) e, em fevereiro de 2010, período anterior ao fim das inscrições para o programa, a empresa contabilizou mais de 1.360 inscritos (HONDA, 2010).

De acordo com as informações de Gomes, os "colaboradores” rapidamente envolveram-se com o programa, tendo em vista a grande novidade que ele 
representava. A princípio, no ato de inscrição no programa, cada participante recebia um prêmio em forma de brinde, como, por exemplo, régua com formas de letras, grafites e outros de origem japonesa. Gomes afirma que no início as apresentações sobre os Círculos eram feitas através de cartazes, pois não havia computadores para auxiliar na apresentação. E então os "colaboradores" usavam as réguas japonesas que recebiam para escrever nos cartazes. Naquele momento, os produtos importados eram difíceis de serem adquiridos, razão pela qual os "colaboradores" sentiam-se prestigiados com o recebimento dos brindes japoneses.

Posteriormente, este programa foi também implantado nas unidades da mesma empresa em São Paulo, mudando sua denominação para Círculo Honda Brasil (CHB). Em 1996, o programa passou a ser executado também na Honda Automóveis e, em 2003, este programa passou a ser chamado e conhecido mundialmente como New Honda Circle (NHC).

De acordo com as informações colhidas na empresa com os instrutores de treinamento, desde sua implantação até 2010, não houve mudanças estruturais no programa, mas apenas mudanças de nomenclatura, devido à disseminação do NHC para as demais empresas do grupo Honda no Brasil e em outros países.

Levando em consideração as informações obtidas no Manual Orientativo para Participantes e Líderes do NHC América do Sul/2007, produzido pela empresa, este círculo tem sua composição formada por um número máximo de cinco e mínimo de quatro "colaboradores" que, por sua vez, reúnem-se espontaneamente, a fim de trocar informações e discutir ideias, com a finalidade de alcançar melhorias ou elaborar soluções para possíveis problemas encontrados no setor onde executam suas funções diárias. Obedecendo a uma estrutura de organização bem delimitada, o círculo tem na sua composição um líder, um secretário, e mais dois ou três membros, no máximo.

No NHC cada participante tem seu papel e função bem definidos. O líder, por exemplo, tem a tarefa de mediar e facilitar a realização das atividades necessárias para o bom desempenho do grupo e deve, ainda, acompanhar o andamento do projeto do seu grupo, levando em consideração os prazos estabelecidos. Além disso, cabe ao líder promover a interação positiva entre os membros do grupo visando a um bom ambiente para o desenvolvimento do trabalho.

Além de todos os membros que compõem o grupo, existe, fora do grupo, a figura do orientador, cuja presença é de grande importância pelo acúmulo de experiência nas atividades do NHC, assim também como pelo conhecimento da filosofia e ferramentas utilizadas no desenvolvimento do programa. Ele pode contribuir também com sugestões e opiniões sobre temas, aconselhar o grupo e criar um ambiente que contribua com o trabalho do grupo. 
Não há um formato padrão de apresentação do resultado do trabalho realizado pelo grupo participante do NHC. No entanto, esta deve ser feita com clareza, de forma objetiva e seguindo as etapas do trabalho. Existe aqui a possibilidade de o grupo optar por um ou mais apresentadores, sem esquecer o limite de tempo dado a cada grupo para realização de sua apresentação. Geralmente as apresentações são feitas em slides com tempo de aproximadamente 15 minutos. No boletim NHC de maio de 2008, o Sr. Chiriro Morimoto, vice-presidente industrial da HAB, comenta a atuação dos brasileiros no NHC, obedecendo o tempo determinado: “Os brasileiros apresentam muito bem. Mostram convicções sobre o que estão falando. Conseguir expressar uma ideia em apenas 15 minutos, tempo que os grupos têm para se apresentarem, também é um aprendizado muito importante" (HONDA, 2008. p. 1).

A apresentação deve ser feita com o auxílio das ferramentas da qualidade: Diagrama de Ishikawa (Espinha de Peixe), Histograma, Gráfico de Pareto, Folha de Verificação, Gráfico de Dispersão, Estratificação, Carta de Controle e Método "GUT", ferramentas que ajudam na clareza e precisão da apresentação das informações.

Cada grupo apresenta seu trabalho através de slides, construídos de acordo com a criatividade da equipe. Todos os gráficos, diagramas e outras ferramentas são apresentados conforme decisão dos membros do grupo. Ou seja, a empresa não interfere na forma como o grupo resolve apresentar o seu trabalho, contanto que no mesmo constem as ferramentas da qualidade sugeridas e ensinadas pela empresa.

Os trabalhos apresentados são iniciados geralmente tendo no primeiro slide o nome do grupo, o ano de produção do NHC e algum possível slogan ou lema da equipe. As ilustrações ficam a critério do grupo. Em seguida, em outro slide são apresentados o tema do trabalho, o nome dos participantes da equipe com ou sem foto, destacando o líder, o apresentador e os demais membros, como também o orientador, acompanhados da descrição e localização do setor em que atuam na fábrica.

Após as apresentações de cada membro e do setor, o cronograma do trabalho é exposto. Na sequência, o "motivo da escolha do tema" começa a ser discutido. Os grupos geralmente apontam em seus trabalhos três possíveis temas a serem trabalhados, pensados e sugeridos pela equipe por meio de uma "tempestade de ideias", ferramenta conhecida como brainstorming. Depois de discutidos e analisados os diferentes temas, um deles é selecionado pela equipe que o abordará através das ferramentas da qualidade como o Diagrama de Ishikawa e o Método GUT. O Diagrama de Ishikawa aponta o motivo do tema por meio da 
localização das possíveis falhas. E as áreas de localização podem ser: qualidade, custo, produção, pessoal ou mão de obra, segurança, equipamentos e, em alguns casos, meio ambiente. Figura 2.

Figura 2. Modelo de utilização do Diagrama de Ishikawa no NHC.

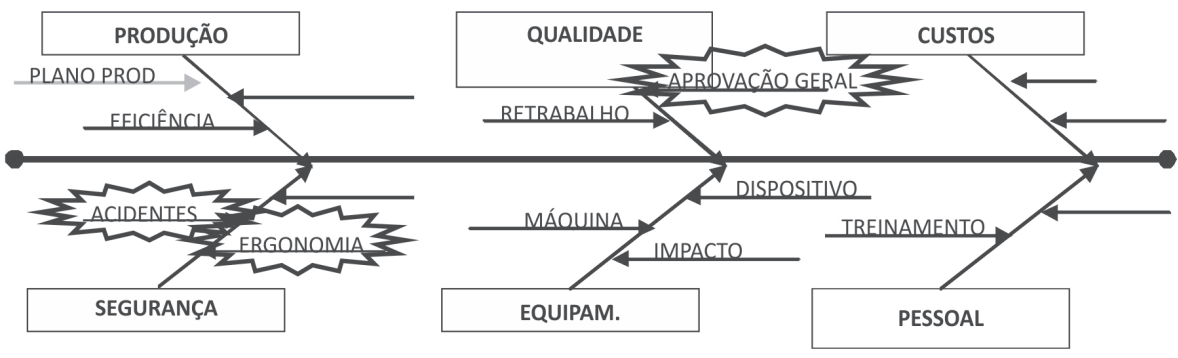

Fonte: Andrade e Valle, 2010

A recomendação da empresa sobre a escolha do tema repousa sobre quatro pontos: 1) dar preferências para a área de atuação do grupo na empresa, para não ter grandes dificuldades quanto ao desenvolvimento do trabalho; 2) ser um bom observador, para investigar, identificar problemas e pontos de melhoria no intuito de elevar a qualidade; 3) reduzir custos, otimizar recursos, melhorar o ambiente de trabalho, trazer benefícios para o ambiente de trabalho, simplificar os processos, eliminar retrabalho e eliminar o desperdício. Outro item da recomendação consiste em analisar e definir o tema considerando o grau de importância do problema e o custo econômico envolvido. A última recomendação é escrever o tema com clareza, devendo este ser a resposta para a expectativa do grupo em relação a determinado problema analisado pela equipe (HONDA, 2009).

Discutido o motivo da escolha e definido o tema, o grupo se empenhará em expor a "situação atual" do processo relacionado ao tema escolhido. A título de exemplo, apresentamos um possível tema: Melhorar a eficiência na inserção do assento " $X$ " da moto modelo " $Y$ ". Nesta fase, a equipe mostrará nos slides a "situação atual" do processo através de gráficos e fotos reais postas em sequência para a apresentação da "análise da situação atual" daquele processo. Concluída a análise da situação atual, os slides mostrarão o motivo pelo qual tal processo se encontra naquela situação; será exposta, então, a "análise das causas", ou seja, o grupo mostrará por meio de alguma ferramenta a causa do problema na situação dada.

O próximo passo do trabalho será fazer uma abordagem clara sobre as "metas e objetivos" pretendidos pelo grupo com a escolha do tema. Geralmente a meta é diminuir algum custo, reduzir algum tempo, aumentar a capacidade de alguma produção e assim sucessivamente. Neste passo, os grupos procuram deixar claro certa diferença entre objetivo e meta, expondo-os separadamente. 
De acordo com o problema encontrado, a fase seguinte será a de sugerir uma "solução" para a sua resolução. Feita a exposição da "proposta de solução", deverá ser apresentada a forma de sua "implantação". Para esta implantação, é aconselhado pela empresa que se faça antes uma avaliação da sua viabilidade econômica, tendo em vista que a implantação será feita pelo "colaborador". Esta implantação deverá possuir um cronograma para sua conclusão, indicando o tempo estimado para que isto ocorra.

Com a implantação concluída, a "análise dos resultados" dessa implantação é apresentada, fazendo referência aos objetivos e metas pretendidos. O grupo deverá apresentar, ainda, algo que possa ser feito para que o mesmo problema não volte mais a acontecer. É a etapa onde se aborda o "freio contra retrocesso". Encerrada a apresentação do trabalho, alguns grupos informam nos slides finais o que pretendem pesquisar no próximo NHC.

A Moto Honda da Amazônia busca aperfeiçoar o relacionamento e o desempenho de seus "colaboradores" nas atividades do NHC e por isso oferece cursos de capacitação e aprendizagem em Ferramentas da Qualidade, Liderança de Equipe e até mesmo um pequeno curso intensivo de Inglês Básico para aqueles que forem apresentar seus trabalhos fora do Brasil.

O New Honda Circle, de certa forma, acabou por trazer um conjunto de conhecimentos técnicos e profissionais para os "colaboradores" da empresa, quer sejam eles líderes ou liderados, quer sejam gerentes ou operadores do chão de fábrica. Esse conhecimento, é claro, terá uma finalidade. Tanto a empresa como os colaboradores acabam usufruindo da produção destes conhecimentos, uma vez que a empresa obtém lucros com os projetos propostos pelos "colaboradores" no NHC e estes, por sua vez, passam a ter suas oportunidades ampliadas.

O programa acaba funcionando como um gerador de oportunidades tanto para a empresa quanto para o colaborador. A empresa diminui custos, melhora a qualidade de seus produtos e os colaboradores ganham maior visibilidade dentro da empresa. O Sr. Gomes, instrutor do "Curso J" da empresa, argumenta:

[...] Esse aprendizado todo fica com a pessoa e a empresa. Quem usufrui disso? Ambos, empregado e empresa, porque a empresa ela começa a colher resultados disso. E o funcionário, o empregado? Ele começa a adquirir conhecimentos técnicos e habilidades pra aplicar isso no dia a dia, para poder desempenhar bem o seu trabalho, e aí, com isso mostrar também a sua capacidade.

Gomes aponta um exemplo de como o colaborador consegue mostrar sua capacidade e outras habilidades que não sejam a de seu trabalho rotineiro na fábrica, em uma empresa com um quadro de funcionário muito grande. Ele explica: 
[...] imagina você, é... numa empresa que tem mais ou menos dez mil funcionários, você passa e vê aí uma população trabalhando; é difícil você olhar e dizer aquele cara ali deve ser bom nisso, isso, naquilo e aquilo ali... não tem como! Você passa lá na linha e vê o cara apertando parafuso. E alguém até erroneamente pode pensar assim: esse cara tá aqui porque só sabe apertar parafuso. Negativo, o cara tem enes habilidades que não dá pra escrever na testa: eu sou bom nisso, sou bom naquilo, não dá. Então o que acontece? O programa de CCQ que é o programa nosso, NHC, quando as equipes são formadas e eles vão mudar uma situação, um tema, por exemplo, um tema (aumentar a eficiência produtiva no processo A), o processo A tá ruim, de vez em quando a linha para. [...] os caras vão fazer algo pra mudar aquilo. Pra produzir mais com menos. E aí tem as etapas de apresentação destes trabalhos. [...] quando eles vão mostrar eles mostram isso pra quem? Existe uma banca que são os jurados. Estes jurados são os chefes dos setores. [...] Então, quando começam a mostrar, começa a despertar o interesse da chefia. Poxa, o trabalho desses caras é interessante, o problema que eles estão abordando é um problema sério aqui na empresa. [...] quando chega lá no final, quem está na banca é o gerente geral, o diretor da empresa, os administradores do Japão e quando é mostrado o resultado o mérito é da equipe e quem é a equipe: José, Antônio Raimundo... e o que o gerente da empresa diria? Esses caras são bons! Eles mudaram uma situação.

Como se observa pelo depoimento do instrutor, para a empresa, o programa NHC gera oportunidades, na medida em que dá ao "colaborador" a possibilidade de se destacar frente à grande massa de trabalhadores empregados.

Há, porém, aqueles que sempre participam das atividades do NHC produzindo ideias e sugestões de melhoria para a empresa, mas que nunca chegam a passar da primeira etapa de classificação. O resultado é o afloramento do sentimento de frustração e desânimo. A secretária geral do NHC em Manaus informou que alguns desses colaboradores chegam até a enviar e-mails discutindo a situação e, em alguns casos, até mesmo xingando. Diante destas situações, a secretária tem que agir de forma cautelosa, a fim de explicar a situação, apontando possíveis falhas na construção, desenvolvimento e apresentação do trabalho no NHC em que aquele "colaborador" encontrava-se envolvido.

Para a participação no programa, os "colaboradores" são estimulados pela empresa a se envolver com as atividades NHC. O estímulo é repassado pelos chefes e coordenadores de setores na empresa.

A filosofia da empresa não incentiva a gratificação financeira para quem participa do programa. Para a Honda, o maior benefício para o participante do CCQ ou NHC está na sua realização pessoal e profissional. No entanto, a empresa disponibiliza pequenos brindes, como bonés, camisas, garrafinhas térmicas, chaveiros, canetas e outros. Estes brindes são considerados pela Honda como prêmios efêmeros diante da possibilidade de maior visibilidade do colaborador, se ele estiver consciente disso. $\mathrm{O}$ orçamento anualmente liberado pela matriz no 
Japão para o NHC prevê verbas para a realização de congressos, compra de brindes, passagens de avião e aluguel de estabelecimentos que disponham de salas para as apresentações dos trabalhos NHC.

Segundo Marcela, secretária geral do NHC em Manaus, a compra dos brindes, passagens e gastos com aluguéis são feitos com descontos. A MHA faz parcerias com outras empresas que, por sua vez, repassam seus produtos a preços mais baixos, como é o caso das passagens de aéreas, conforme depoimento da secretária:

[...] quando chega a hora de viajar pra toda essa equipe, né? Que já é negociado a preço mais barato. Agente freta o avião, que justamente o avião desse ano, que no ano passado foi cento e vinte e cinco pessoas num avião. Só da Honda eram noventa e cinco. Aí tem um custo mais baixo, né? Então a gente consegue fazer aí... que era uma época de crise, tinha que negociar bastante. Tem que negociar, eu tenho que ter três fornecedores e negociar com os três.

De acordo com as informações da empresa, todos os trabalhos NHC são desenvolvidos de forma voluntária, porém existem cobranças em torno da formação de grupos. Os "colaboradores" não são obrigados a participar das atividades do CCQ; no entanto, o seu grau de envolvimento com as atividades desenvolvidas na empresa, quaisquer que sejam, contará nas avaliações que a empresa anualmente faz sobre seus "colaboradores", conforme se depreende do depoimento da secretária geral do NHC:

Se eu não faço conta na minha avaliação de desempenho... se eu não estou participando desta atividade da empresa. [...] não é penalizado, nunca ninguém foi penalizado por questão de NHC. Só que é aquela questão assim, eu estou aqui só pra apertar o meu botão e nada mais. Então se você não está colaborando pra empresa e nem pra você mesmo, então você não quer crescer. [...] a empresa não prejudica - é que nem você estar na escola, tu tem o teu TCC eu vou estudar, estudar, estudar, final do ano, ah! Não vou fazer... também não vou formar.

O maior número de grupos formados encontra-se no setor com maior número de funcionários. No caso, a área de fundição. Mas também os outros setores desenvolvem seus projetos e concorrem com outros setores. O grupo que desenvolver o melhor trabalho terá a oportunidade de apresentá-lo fora do Brasil, no Japão ou em outros países escolhidos pela empresa.

Cada "colaborador" desenvolve o seu trabalho como de costume em sua linha ou em seu setor, segundo a função para o qual foi contratado. Para o desenvolvimento dos trabalhos NHC, esse "colaborador" irá utilizar os tempos livres que ele dispõe dentro da empresa, em geral, a parte do tempo destinado para almoçar. Outrora, os "colaboradores" produziam seus trabalhos em suas 
casas, realizando reuniões de suas equipes para discutir o projeto. Era assim desde a implantação do New Honda Circle em 1981, conforme consta no Boletim NHC de maio de 2008, referindo-se a dois "colaboradores" que participaram de um dos primeiros grupos:

$\mathrm{Na}$ época, ambos atuavam na linha de montagem e o tempo para desenvolver os projetos já era escasso. Em função disso, as pessoas se reuniam no final de semana, na casa de um dos membros do grupo, o que, segundo eles, criava maior integração entre as pessoas e refletia positivamente no ambiente de trabalho (HONDA, 2008).

Atualmente existe um programa de segurança de informação que impede que as informações saiam da empresa, razão pela qual todos os trabalhos NHC devem ser desenvolvidos no interior dela mesma. Pensando nisso, alguns coordenadores na empresa, visando a um melhor ambiente de trabalho para o "colaborador" e buscando gerar uma maior participação dos trabalhadores no CCQ, transformam alguns espaços da empresa em ambientes para discussão e produção NHC.

Existem trabalhos com os mais diversos temas, uns tratando de segurança, outros de ergonomia, redução de resíduos, custos etc. Todos esses trabalhos, independente do tema ou da área abordada, têm como propósito a redução de custos para a empresa. Como exemplo, podemos citar um trabalho destinado à área de ergonomia, que guarda relação com a saúde do "colaborador" e os movimentos repetitivos: se for produzido um bom trabalho e houver diminuição de casos relacionados à saúde ou ao afastamento do trabalhador, certamente que ocorrerá uma melhora significativa nas condições de trabalho, gerando melhorias para o "colaborador", mas também a empresa será grandemente beneficiada com a redução de gastos com apoio a "colaboradores" doentes ou afastados em decorrência do trabalho.

Alguns projetos produzidos no NHC são tão importantes e tão marcantes que chegam a alterar a produção e a organização do trabalho realizado nas linhas de produção e outros setores. Segundo a secretária geral do NHC, esses tipos de trabalhos devem ser feitos com cautela e muita atenção para não comprometer a participação de outros “colaboradores” dentro da empresa. Ela nos dá um exemplo:

$\mathrm{Na}$ fabricação do assento, quando você joga a espuma tem um carrossel aí tinha umas folgas de uma pra outra então eu falei: porque que não bota mais carrossel aqui, né? Que vai fazer mais assento. Aí se botasse isso ia diminuir um colaborador, aí ia ter que demitir um funcionário, isso a equipe reunida. Então vamos fazer o seguinte: a gente não tira esse colaborador, diminui o tempo da esteira que é o tempo que ela fica na estufa, ela vai e enche e essa pessoa aqui ela depois como o volume de assento vai ser muito maior ele vai ficar lá pra retirar o assento. A gente só tirou ele da atividade que ele fazia que era encher, que ficava dois enchendo e botamos ele já pra tirar os assentos que acaba sendo feito com mais velocidade, 
saindo muito mais assento do que o esperado. Não precisou eliminar funcionário, mesmo que retirasse, a gente reduziu hora extra, que antes era feita hora extra, então tem todo um segmento.

Os trabalhos produzidos pelos "colaboradores” neste programa são considerados concluídos somente quando os projetos sugeridos são implantados no local planejado". "Trabalho concluído é trabalho implantado", afirma Marcela.

A empresa não disponibiliza nenhuma verba para a implantação do projeto, limitando-se a dar suporte para que isso ocorra através da colaboração de funcionários de áreas como engenharia, mecânica e outras. Conforme a Filosofia Honda, cada colaborador deve responsabilizar-se pela sua própria criação.

\section{CONCLUSÃO}

Os estudos e análises realizados revelaram algumas características do modelo japonês, destacando-se as práticas gestionárias relacionadas à mobilização e organização dos trabalhadores, com vistas à sua participação e envolvimento nos processos decisórios relacionados a custo, qualidade e produtividade.

De origem japonesa, a filosofia de gestão do trabalho presente na Moto Honda da Amazônia (MHA), locus da pesquisa, tem no envolvimento, participação e colaboração dos trabalhadores os seus princípios fundamentais e constitutivos dos novos paradigmas do trabalho, entre os quais o modelo japonês é exemplar. Os programas de melhoria adotados pela MHA no cotidiano fabril são ilustrativos das práticas gestionárias utilizadas para promover o envolvimento e obter o comprometimento do trabalhador com a resolução e prevenção de problemas e, por consequência, a melhoria contínua.

O New Circle Honda apresentou-se como o principal instrumento, através do qual a empresa vem promovendo a inserção dos trabalhadores, chamados de "colaboradores", no cotidiano do espaço fabril. Este programa recebeu diferentes denominações ao longo das últimas décadas, mas a sua natureza e o seu conteúdo não sofreram alterações: fazer do trabalhador um "colaborador" comprometido com a qualidade e a produtividade da empresa.

A transferibilidade do modelo japonês para a Moto Honda da Amazônia, empresa subsidiária da Honda Motor Co. Ltd. fez-se, desde o início da década de 1980, predominantemente através de uma política de gestão caracterizada pelo trabalho em equipe e pelo compromisso do trabalhador, que exigem que cada um deles busque, de forma permanente, melhorar a sua capacidade de trabalho e a sua

9 Em geral, o período das atividades no NHC (início e conclusão dos trabalhos) é de 12 meses. 
qualificação. A busca pela melhoria contínua implica a busca de uma permanente aquisição, pelo trabalhador, de novas capacidades cognitivas e comportamentais para melhor desempenho de sua função no posto que ocupa, e maior envolvimento no trabalho em equipe. Implica, ainda, pela empresa, a promoção de cursos e treinamentos, visando o aperfeiçoamento da base técnica de produção e também do perfil do trabalhador que, identificado com a filosofia da MHA, desempenha suas atividades orientado pelas Três Alegrias, pelos princípios do respeito e da confiança mútuos.

Os trabalhadores são "motivados" a participar dos programas de melhoria contínua através de pressões sub-reptícias que remetem ao compromisso do trabalhador com a empresa, à responsabilidade quanto ao seu crescimento profissional e sentimento de autorrealização que são proporcionados a partir de sua participação nesses programas.

A participação do trabalhador nas atividades do NHC é obtida por meio de pressões exercidas pela empresa e que se revelam no acesso às promoções previstas no plano de cargos e salários: os participantes do NHC são mais visíveis quando o assunto é promoção, o que significa que os não participantes ficam excluídos ou, pelo menos, mais vulneráveis à exclusão no momento de decidir quem será promovido. A disponibilização de brindes também tem sua importância nesta relação, pois traz, de certa forma, uma parcela de satisfação ou recompensa pelo esforço dispendido no interior dos programas de melhoria contínua.

O desenvolvimento das atividades executadas no âmbito dos programas de melhoria contínua, como, no caso estudado, o New Honda Circle, trouxe evidentemente algumas mudanças sobre a jornada de trabalho dos "colaboradores", na medida em que o tempo disponível para o almoço passou a ser utilizado como tempo para a realização das atividades do NHC, o que subtrai o tempo para a alimentação, o descanso e o diálogo com os demais trabalhadores da empresa.

O discurso produzido pela empresa junto aos trabalhadores, de geração de oportunidades, de visibilidade e de obtenção de posição de destaque junto aos demais “colaboradores", participantes ou não do NHC, é claramente um recurso retórico de forte apelo junto ao conjunto dos trabalhadores empregados, invisíveis que são enquanto permanecem como massa indivisível no processo de produção de veículos sobre duas rodas. 


\section{REFERÊNCIAS}

CORIAT, B. Ohno e a Escola japonesa de gestão da produção: um ponto de vista do conjunto. In: HIRATA, H. (Org.). Sobre o "Modelo" japonês. São Paulo: Edusp, 1993.

Pensar pelo avesso. Rio de Janeiro: Revan, 1994.

HARVEY, D. A condição pós-moderna. São Paulo: Loyola, 1989.

HIRATA, H. (Org.). Sobre o “modelo” japonês. São Paulo: Edusp, 1993.

HIRATA, H. Receitas japonesas, realidade brasileira. Novos Estudos CEBRAP, 2. São Paulo, 1983.

HONDA, Moto. Boletim NHC. Linkpress Assessoria e Comunicação, 2008.

HONDA, Moto. Espaço Honda, ano VI, n. 46, Mar./Abr., 2010.

HONDA, Moto. Espaço Honda, ano VI, n. 45, Jan./Fev., 2010.

HONDA, Moto. Espaço Honda, ano V, n. 44, Nov./Dez., 2009.

HONDA, Moto. Espaço Honda, Ano V, n. 43, Set./Out., 2009.

HONDA, Moto. Espaço Honda, Ano V, n. 42. Jul./Ago., 2009.

HONDA, Moto. Espaço Honda, Ano V, n. 40, Mar./Abr., 2009.

HONDA, Moto. Espaço Honda, Ano IV, n. 29, Abr./Maio, 2007.

HONDA, Moto; NHC Circle Manual para membros e líderes. América do Sul. [s.n.], 2007.

HONDA Motor Co., Ltd.: Filosofia Honda, 1998.

HONDA, Moto. Honda: 25 anos de Brasil. Coordenação geral Maia Mendonça. São Paulo: DBA Artes Gráficas, 1997.

HUMPHREY, J. O impacto das técnicas japonesas de administração sobre o trabalho industrial no Brasil. In: CASTRO, N. A. de (Org.). A máquina e o equilibrista. Rio de janeiro: Paz e Terra, 1995.

IMAI, M. Kaizen - a estratégica para o sucesso competitivo. São Paulo: IMAI, 1988.

KERN, H.; SCHUMANN, M. Limits of the Division of labour. New production and employment concepts in West German Industry. Economic and Industrial Democracy, Londres, v.8., 1989. 
MELO, E. L. A Formação de Rede de Produção na Indústria de Veículos Sobre Duas Rodas no Norte Brasileiro. 2010. Dissertação (Mestrado) - PPGS/ UFAM, Manaus, 2010.

MORAES, R. D. de. Prazer-sofrimento no trabalho com automação: estudo em empresas japonesas no Polo Industrial de Manaus. Manaus: Editora UFAM, 2010. PIORE, M.; SABEL, C. The second industrial divide. New York: Basic Books, 1984.

RUAS, R.; ANTUNES, J. S.; ROESE, M. Avanços e impasse do modelo japonês no Brasil: observações acerca de casos empíricos. In: HIRATA, H. (Org.). Sobre o “Modelo" Japonês. São Paulo: Edusp, 1993.

SALERNO, M. Produção, trabalho e participação: CCQ e Kanban numa nova imigração japonesa. 1985. Dissertação (Mestrado) - COPPE/UFRJ/PEP, Rio de Janeiro, 1985.

SUFRAMA. Superintendência da Zona Franca de Manaus. Catálogo de empresas e produtos. polo Industrial de Manaus. Setor de duas rodas. Disponível em: < http.www.suframa.gov.br.publicacoessite_pimduasrodas.htm>. Acesso em: 22 nov. 2009.

WOOD, S. O modelo japonês em debate: pós-fordismo ou japonização do fordismo. RBCS. Rio de Janeiro: Relume Dumará, n. 17, 1991.

Toyotismo e/ou japonização. In: HIRATA, H. (Org.). Sobre o “Modelo" japonês. São Paulo: Edusp, 1993. p.49-77.

VALLE, I. Globalização e reestrutura produtiva: um estudo sobre a produção offshore em Manaus. Manaus: Editora UFAM, 2007. 